4. Johnson-Wood, K. et al. Proc. Natl Acad. Sci. USA 94, 1550-1555 (1997).

5. Price, D. L. \& Sisodia, S. S. Annu. Rev. Neurosci. 21, 479-505 (1998).

6. Hsia, A. et al. Proc. Natl Acad. Sci. USA 96, 3228-3233 (1999).

Raber, J. et al. Proc. Natl Acad. Sci. USA 95, 10914-10919 (1998).

. Buttini, M. et al. J. Neurosci. 19, 4867-4880 (1999).

9. Lue, L.-F. et al. Am. J. Pathol. 155, 853-862 (1999).

10. McLean, C. A. et al. Ann. Neurol. 46, 860-866 (1999).

11. Holcomb, L. A. et al. Behav. Genet 29, 177-185 (1999).

12. Lambert, M. P. et al. Proc. Natl Acad. Sci. USA 95, 6448-6453 (1998)

13. Hartley, D. M. et al. J. Neurosci. 19, 8876-8884 (1999).

Environmental microbiology

\section{A tetrodotoxin-producing marine pathogen}

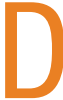

sease-related mortalities of sea urchin populations have occurred globally over the past 20 years, although the causative agents have rarely been identified $^{1}$. We have discovered a potent new marine pathogen that caused a sudden die-off of the sea urchin Meoma ventricosa in Curaçao, Netherlands Antilles, in January of 1997 (ref. 2), and which also has implications for human health. This turns out to be a neurotoxin-producing bacterium that is closely related to the deadly Pseudoalteromonas haloplanktis tetraodonis, which is responsible for numerous deaths each year in Japan resulting from the consumption of pufferfish ${ }^{3-5}$.

The most extensive epizootic reported for sea urchins occurred in the early 1980s, with populations of Diadema antillarum being affected throughout the Caribbean sea and western Atlantic: some areas lost more that $97 \%$ of mature animals ${ }^{6,7}$. The ecological impact of the D. antillarum die-off on coral reefs was profound, resulting in a dramatic increase of algal cover, which in turn reduced the settlement rates of coral larvae $e^{7,8}$.

$M$. ventricosa inhabits sandy sediment adjacent to and within sea-grass beds and patch reefs throughout the Florida reef tract and the Caribbean. The die-off in Curaçao extended from the Curaçao harbour to an area $3.5 \mathrm{~km}$ downcurrent along the coast ${ }^{2}$. Necropsy of infected animals revealed a progressive loss of spines associated with the disease. Microscopic comparison of the base of the spines and the catch apparatus (where the spine is connected to the skeleton) from affected and healthy animals revealed Gram-negative bacteria in diseased tissue. We isolated these bacteria using a non-selective artificial seawater medium ${ }^{9}$ : in all 249 bacterial strains were found in various tissues associated with affected and unaffected urchins.

We exposed these isolates to 95 different carbon sources by using a Biolog microplate assay system $^{9,10}$. Two metabolic groups (VL1 and PL-1) were found to occur only in affected tissue (Fig. 1a), so we tested these

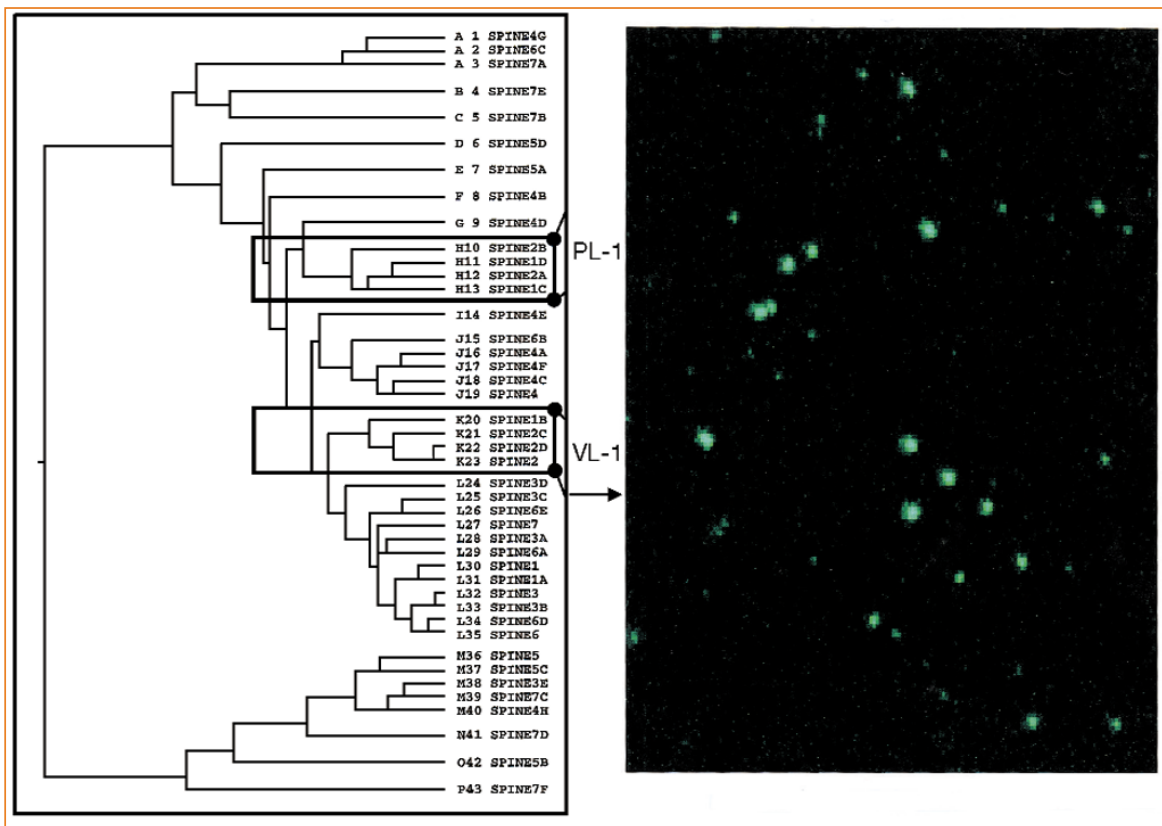

Figure 1 Identification of the new species of tetrodotoxin-producing bacterium. a, Dendrogram showing metabolic relationships among bacterial strains isolated from $M$. ventricosa spine catch apparatus. Dendrograms were constructed by clustering hierarchical trees using a nearest-neighbour unweighted pair-group averaging cluster analysis. Isolates PL-1 and VL-1 were indicated as possible pathogens from this grouping. $\mathbf{b}$, Immunoassay of the pathogenic isolate VL-1. Fluoroscein isothiocyanate-conjugated anti-mouse lgG (green fluorescence) can be seen bound to anti-tetrodotoxin mouse IgG bound to cells producing tetrodotoxin (TTX). Cells were viewed using a confocal laser microscope.

isolates for pathogenicity by infecting the urchin Lytechinus variegatus. Aquaria trials with the two isolates showed that urchins inoculated with isolate VL-1 started to shed their spines after two days, whereas control and PL-1-treated urchins remained healthy for over three weeks. We therefore re-isolated VL-1 from the catch apparatus of experimentally infected urchins.

Using DNA-sequence analysis of small ribosomal RNA (16S rDNA), we identified VL-1 as a new bacterium closely related to Pseudoalteromonas haloplanktis subsp. tetraodonis ${ }^{11}$, which produces tetrodotoxin ${ }^{2}$ (GenBank accession number, AF154414). Tetrodotoxin has been isolated from various marine organisms, but is best known for its association with pufferfish (order Tetraodontiformes): poisoning by pufferfish (fugu) consumption remains a major health concern, primarily in Japan, where fugu is a delicacy ${ }^{4}$. We tested whether our VL-1 isolate could also produce tetrodotoxin by exposing three-day cultures of VL-1 and PL-1 (as a control) to anti-tetrodotoxin mouse IgG, followed by fluoroscein-conjugated anti-mouse $\operatorname{IgG}^{12}$. We found that a subset of these isolates in the culture could produce tetrodotoxin (Fig. 1b).

To our knowledge, this is the first report of an epizootic affecting $M$. ventricosa. Although the ecological consequences of this urchin die-off are unclear and this epizootic is possibly an isolated incident, it is becoming increasingly important to identify the agents responsible for marine mortality events. In addition, this is the first time that a tetrodotoxin-producing bacterium has been found to cause disease in a marine animal. And because many urchin species are commercially valuable, our demonstration that this bacterium can cause identical disease symptoms in a different sea urchin species is an important consideration.

Kim B. Ritchie*, Ivan Nagelkerken $\dagger$, Sara Jamesł, Garriet W. Smith§

${ }^{*}$ Department of Biology, University of North Carolina, Chapel Hill, North Carolina 27599-3280, USA

†Carmabi Foundation, PO Box 2090, Piscaderabaai $z / n$, Curaçao, Netherlands Antilles

$\ddagger$ Department of Microbiology and Molecular Medicine, Clemson University, Clemson,

South Carolina 29634-1908, USA

$\$$ Biology Department, University of South Carolina, Aiken, South Carolina 29801, USA

e-mail:Smithres@aiken.sc.edu

1. Peters, E. C. in Pathobiology of Marine and Estuarine Oganisms (eds Couch, J. \& Fournie, J.) 393-449 (CRC Press, Boca Raton, 1993

2. Nagelkerken, I., Smith, G. W., Snelder, E., Karel, M. \& James, S Dis. Aquat. Org. 38, 71-74 (1999).

. Yotsu, M. et al. Toxicon 25, 225-228 (1987).

4. Noguchi, T. et al. Mar. Biol. 94, 625-630 (1987). Appl. Enivron. Microbiol. 53, 1714-1715 (1987).

6. Lessios, H. A., Robertson, D. R. \& Cubit, J. D. Science 226 , 335-337 (1984)

Hughes, T. P. Science 265, 1547-1551 (1994)

8. Lessios, H. A. Annu. Rev. Ecol. Syst. 19, 371-393 (1998).

9. Ritchie, K. B. \& Smith, G. W. Mol. Mar. Biol. Biotechnol. 4 , 345-352 (1995).

10. Bochner, B. R. Nature 339, 157-158 (1989).

11. Martinez-Murcia, A. J., Benlloch, S. \& Collins, M. D. Int. J. Syst. Bacteriol. 42, 412-421 (1992).

12. Brigmon, R. L. \& De Ridder, C. Appl. Environ. Microbiol. 64, 3491-3495 (1998)
5. Simidu, U., Noguchi, T., Hwang, D. F., Shida,Y. \& Hashimoto, K. 